\title{
Can the leaf age influence the susceptibility to bacterial- leaf-spot and bacterial-halo-blight on coffee seedlings?
}

\author{
A idade das folhas pode influenciar na suscetibilidade de cafeeiros à \\ macha-foliar-bacteriana e à mancha-aureolada?
}

\begin{abstract}
Ana Laura Midori Rossi Tomiyama', Lucas Mateus Rivero Rodrigues ${ }^{1 *}\left(\mathbb{D}\right.$, Vinicius Teixeira Andrade ${ }^{1}$, Luis Otavio Saggion Beriam ${ }^{2}\left(\mathbb{D}\right.$, Suzete Aparecida Lanza Destéfano ${ }^{2}$ (D), Oliveiro Guerreiro Filho' ${ }^{10}$
\end{abstract}

\begin{abstract}
Pseudomonas syringae van Hall, 1902, causes yield losses in innumerous economic important crops. On coffee trees, P. syringae pv. garcae causes the bacterial-halo-blight (BHB) and $P$. syringae pv. tabaci the bacterial-leaf-spot (BLS). Recently, these diseases incidence has increase in occurrence areas and aggressiveness in Brazil. Although leaf age plays a role in the severity response of $\mathrm{BHB}$, it is not known yet if this phenomenon also occurs in coffee-BLS interaction, and with highly virulent strains. So, we examined differences in the diseases severity by inoculation of $P$. syringae pv. garcae and $P$. syringae pv. tabaci strains on coffee leaves with different ages, to compare this aspect with coffee-BLS interaction. Our results showed that, for both pathovars, the severity was greater at the first internodes leaves, although for the most aggressive strains it was quite similar on any leaf age.
\end{abstract}

KEYWORDS: Pseudomonas syringae pv. garcae; P. syringae pv. tabaci; area under the disease progress curve; diseases severity.
RESUMO: Bactérias da espécie Pseudomonas syringae van Hall, 1902, causam perdas na produção em inúmeras culturas de importância econômica. Em cafeeiros, P. syringae pv. garcae provoca a mancha-aureolada e P. syringae pv. tabaci ocasiona a mancha-foliar-bacteriana, doenças cuja ocorrência e agressividade têm aumentado nos últimos anos no Brasil. Embora a idade das folhas influencie na expressão da severidade de mancha-aureolada, não se sabe ainda se essa influência se mantém em plantas infectadas por estirpes altamente virulentas da bactéria. Desse modo, o presente estudo foi realizado com a finalidade de examinar diferenças na severidade de mancha-aureolada em folhas de cafeeiro com diferentes idades, bem como estudar comparativamente tais aspectos na interação entre cafeeiro e mancha-foliar-bacteriana, empregando-se isolados altamente virulentos. Os resultados evidenciaram que, assim como a mancha-aureolada, a severidade da mancha-bacteriana também é maior em folhas jovens do primeiro internódio, entretanto, as estirpes mais agressivas de $P$. syringae pv. garcae e $P$. syringae pv. tabaci provocaram danos de magnitude semelhantes em folhas de diferentes idades, do primeiro ao quinto internódio.

PALAVRAS-CHAVE: Pseudomonas syringae pv. garcae; Pseudomonas syringae pv. tabaci; área abaixo da curva de progresso da doença; severidade da doença. 
Among the bacterial diseases of coffee Coffea arabica L., Pseudomonas syringae pv. garcae (AMARAL et al., 1956; YOUNG et al., 1978), causal agent of bacterial-halo-blight-of-coffee (BHB), and P. syringae pv. tabaci (WOLF; FOSTER, 1918; YOUNG et al., 1978), responsible by bacterial-leaf-spot (BLS) (DESTÉFANO et al., 2010), stand out owing their dissemination and damage caused in the coffee crop. In Brazil, the BHB is the disease better known and disseminated in main production areas of coffee. It is a hard managed disease, and outbreaks have occurred frequently in regions with high relative humidity and high inoculum potential. So, the use of genetic resistance could be an effective control strategy (SERA, 2001).

The selection of resistant coffee plants is usually made on field (ITO et al., 2008) and greenhouse conditions (MOHAN et al., 1978; RODRIGUES et al., 2017a). However, the spatial dispersion of bacteria inoculum on field conditions is not uniform, leading to unreliable responses and failure to select the best plants. Under greenhouse conditions, the early coffee plant selection is feasible and more accurate. Then, the correct evaluation method is required, such bacteria strains, inoculum concentration, inoculation methods, host tissue development stage and disease symptoms evaluation method.

Owing the importance of $\mathrm{BHB}$, numerous studies have clarified the epidemiological aspects of the disease. A remarkable characteristic of BHB is the differential susceptibility response on young and mature leaves (OLIVEIRA; ROMEIRO, 1990). According to OLIVEIRA; ROMEIRO (1990), young leaves are more susceptible than the physiologically mature ones, probably because the action of phenolic compounds, rather concentrated in this tissue (OLIVEIRA; ROMEIRO, 1991; OLIVEIRA et al., 1991). In these investigations, only one bacterial strain was tested, and, so, it is unknown if the leaves age could influence the susceptibility of plants inoculated with highly aggressive strains.

BLS is not a well-known disease as BHB. It was first reported a decade ago infecting coffee nurseries at south of São Paulo state (SP) (DESTÉFANO et al., 2010). Nowadays, BLS has been reported in north of Paraná state (PR) on individual and/or simultaneous infection with BHB. The diagnostic could be inaccurate due to the very similar symptoms of both (RODRIGUES et al., 2017b).

Information regarding the epidemiological aspects of the BLS are lacking, and little knowledge exists about the virulence of different strains on coffee plants. Also, it is unknown if the leaf age can affect the BLS severity, and this information could be important to screening resistant coffee plants in breeding programs.

In this work, we investigated the virulence variability of BLS strains, as well as possible interactions between virulence of BHB and BLS strains and diseases severity on different age of leaves.

Bacterial strains used in this study were obtained from the Phytobacteria Culture Collection of Instituto Biológico
(IBSBF): two strains of Pseudomonas syringae pv. garcae, IBSBF 3212 (Getulina, SP) and IBSBF 1197 (Campinas, SP); and three strains of P. syringae pv. tabaci IBSBF 2249 (Arandu, SP), IBSBF 3210 (Cascavel, PR) and IBSBF 3211 (Londrina, PR).

Bacterial suspensions in saline $(\mathrm{NaCl} 0.85 \%)$ were obtained from pure colonies grown in nutrient agar medium for $48 \mathrm{~h}$ at $28^{\circ} \mathrm{C}$. The inoculum was adjusted for the final concentration of approximately $10^{8} \mathrm{CFU} . \mathrm{mL}^{-1}$ (colony-forming unit) in spectrophotometer $(600 \mathrm{~nm}$ wavelength and 0.22 of absorbance) (LELLIOT et al., 1966).

Virulence determination was evaluated by strains inoculation on five pairs of leaves of the Catuai Vermelho IAC 81 cultivar, susceptible to BHB and BLS, and the Ethiopian landrace IAC 2160, as resistant control for BHB. The reaction of the IAC 2160 to the BLS has not been established yet. The strain IBSBF 1197 of $P$. syringae pv. garcae was used as high virulence control (RODRIGUES et al., 2017a).

The experiments were carried out at Centro Avançado de Pesquisa em Proteção de Plantas e Saúde Animal, in Campinas, SP, Brazil.

The inoculations were performed by abrasion method on abaxial surface of the leaves, in accordance with RODRIGUES et al. (2017a). Control plants were inoculated with saline $(\mathrm{NaCl} 0.85 \%)$. After inoculation, the plants were kept in greenhouse conditions with controlled irrigation to promote high relative humidity (70-80\%).

The disease development was evaluated on leaves from first to fifth internode at 7, 19, 26 and 31 days after inoculation (DAI). The severity was estimated attributing 0 to 5 points of a disease rating scale (DRS), according to the type of reactions and the percentage of the visual symptoms of the disease. The data were used to calculate the area under the disease progress curve (AUDPC) (VAN DER PLANK, 1963), as determined by the formula described in Equation 1:

$\sum_{i=1}^{n-1}\left(\frac{y_{i}+y_{i+1}}{2}\right) *\left(t_{i+1}+t_{i}\right)$

In which:

$n=$ the total number of observations;

$y_{i}$ and $y_{i+1}=$ the values of points of the disease rating scale, relative to the severity of the disease in the $\mathrm{i}$-th observation; $\left(t_{i+1}-t_{i}\right)=$ the interval between evaluations.

The virulence degree was determined by means of the AUDPC values, obtained in leaves of the first five internodes of coffee plants Catuaí Vermelho IAC 81 cultivar and the land race IAC 2160.

The experimental design was completely randomized, treatments in a factorial arranged with five replications and one plant per plot, according to the statistical model presented in Equation 2: 
$y=X_{r}+W_{i}+e$

In which:

$\mathrm{y}=$ the data vector;

$r=$ the vector representing the constant, bacterial strains virulence and pair of leaves fixed effects;

$i=$ the vector of virulence of strains and pair of leaves interaction;

$e=$ the error vector, $e-N\left(0, I \sigma_{\mathrm{e}}^{2}\right)$;

$X$ and $W=$ the incidence matrices of the $r$, and $i$ vectors, respectively.

The Student-Newman-Keuls test (STEEL; TORRIE, 1980), with $5 \%$ of significance level, was used in order to compare means of AUDPC data. The analysis of variance and mean test were performed according to PROC GLM, of SAS program (STATISTICAL ANALYSIS SYSTEM INSTITUTE, 2009).

The inoculation results showed that the five $P$. syringae strains were pathogenic on all pairs of leaves of Catuaí Vermelho IAC 81 susceptible cultivar. The IAC 2160 landrace revealed to be resistant to the five strains, and the resistance reaction was verified since the first evaluation at 7 DAI (Fig. 1). Control plants inoculated with saline remain healthy during experimental period.

Atypical resistance reactions were observed at $7 \mathrm{DAI}$ on the fourth and fifth leaves of IAC 2160 to P. syringae pv. garcae (Fig. 1, M and Q) and to P. syringae pv. tabaci (Fig. 1, O and S), when compared to those observed on younger leaves. These atypical reactions were characterized by depressed and discolored tissues, with slight orange-yellowish halo around the lesions. These symptoms remain until the end of the experiment (31 DAI).

Statistical analysis of AUDPC of the BHB and BLS on the different leaves age was performed with data obtained from Catuaí Vermelho IAC 81 cultivar, since the progenies of IAC 2160 access were resistant to both diseases.

The sources of variation bacterial strains and leaf age and their interaction were significant in the analysis of disease severity (Table 1 ).

The AUDPC mean values analysis revealed the P. syringae $\mathrm{pv}$. garcae IBSBF 1197 strain and the $P$. syringae pv. tabaci IBSBF 3210 and IBSBF 2249 strains were the most virulent, while P. syringae pv. garcae IBSBF 3212 strain showed intermediary virulence and $P$. syringae pv. tabaci IBSBF 3211 strain the exhibited lower values of virulence on Catuaí Vermelho IAC 81 cultivar (Table 2 ).

The disease severity on leaves was statically high in first and fifth pairs and lower in second to forth leaves according to the AUDPC means values. As determined by statistical analysis, the strains IBSBF 1197 of $P$. syringae pv. garcae and IBSBF 3210 of $P$. syringae pv. tabaci caused equal diseases severity on leaves from the first to the fifth leaf pair (Table 2).

Lesions developed by P. syringae pv. garcae IBSBF 3212 strain and $P$. syringae pv. tabaci IBSBF 3211 strain showed moderate and low virulence, respectively, on Catuaí Vermelho IAC 81 cultivar, although IBSBF 3212 indicated symptoms more pronounced on leaves of the first and fifth internodes, while IBSBF 3211 presented to be more virulent in fifth pair of leaves (Table 2).

Our results corroborate the information of the influence of leaf age on the $\mathrm{BHB}$ response on susceptible coffee plants, previously reported by OLIVEIRA; ROMEIRO $(1990,1991)$, ZOCCOLI et al. (2011) and RODRIGUES et al. (2017a). However, bacterial strains characterized by high degree of virulence, such as IBSBF 1197, induced BHB symptoms on the Catuaí Vermelho IAC 81 cultivar equally severe on younger and older leaves, while the less aggressive strains, such as IBSBF 3212, resulted lower disease severity on leaves of second to fourth internodes. The virulence of strains and/ or host susceptibility information are indispensable to conducting early resistant plants selection in breeding programs aiming new cultivars.

Few information of the BLS-C. arabica interaction is available on the literature. However, the occurrence of simultaneous infection by BHB and BLS on Arabica coffee (RODRIGUES et al., 2017b) reveals the importance of selection and development of new cultivars with multiple resistance to pathogens.

Results of AUDPC analysis of $P$. syringae pv. tabaci strains revealed the existence of virulence variability on Catuaí Vermelho IAC 81 cultivar. Despite the limited number of BLS strains, the IBSBF 3210 and IBSBF 2249 strains were significantly more aggressive than IBSBF 3211 (Table 2).

In addition, the interaction between leaves age and BLS severity on susceptible coffee plants varied according to the virulence of $P$. syringae pv. tabaci strains. No statistical difference was observed from the first to the fifth pair of leaves inoculated by IBSBF 3210 strain. On the other hand, the disease caused by IBSBF 3211 and IBSBF 2249 strains resulted in variable severity on inoculated leaves, with lower AUDPC values on the third pair (Table 2).

Although the evidence that the physiological leaf stage influences on the diseases response of susceptible coffee cultivar, in general the evolution of BHB and BLS, by infection of moderate or less virulent strains, can be delayed on leaves with higher metabolic activity.

Some previous results indicate that coffee young leaves are more susceptible to $\mathrm{BHB}$ than those fully developed leaves (OLIVEIRA; ROMEIRO, 1990, 1991; OLIVEIRA et al., 1991; ZOCCOLI et al., 2011; RODRIGUES et al., 2017a). Nevertheless, according to OLIVEIRA; ROMEIRO (1990), high inoculum concentrations may result in similar damages on young and mature leaves.

As determined by our results, differential leaves diseases response occurs when the coffee plants are infected by lower to moderate virulent strains of BHB and BLS, evidencing that the host response is mainly due to the strains virulence, in detriment of the inoculum pressure exerted by 
P. syringae pv. garcae IBSBF 3212
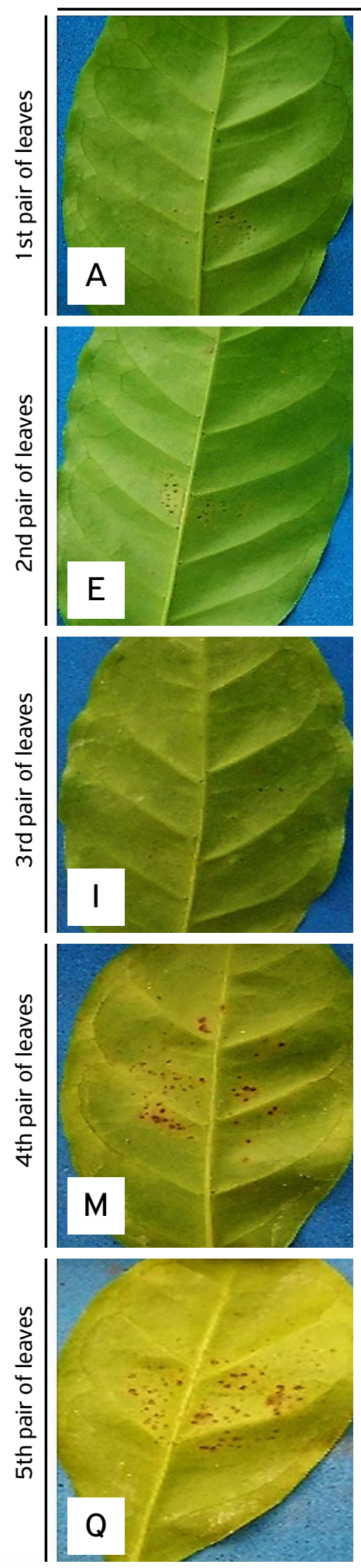

IAC 2160
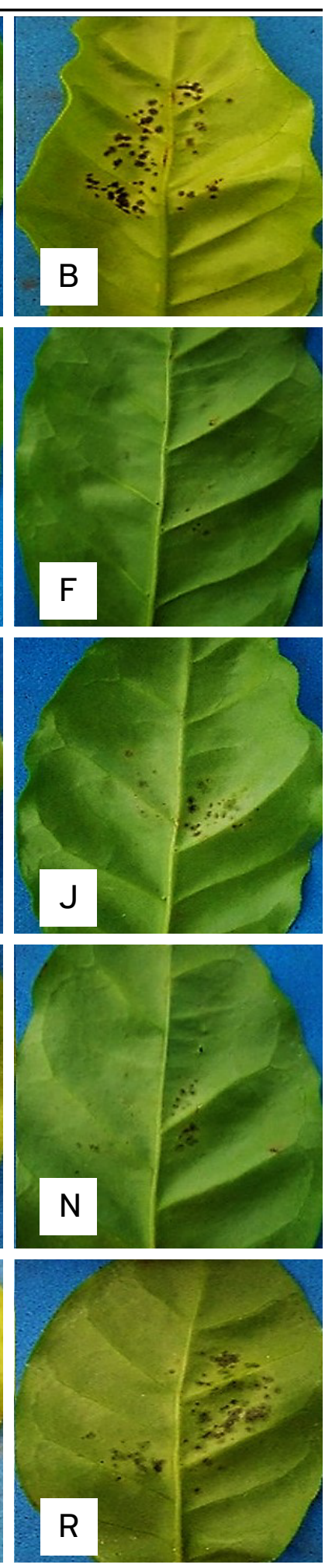

IAC 81
P. syringae pv. tabaci IBSBF 3210
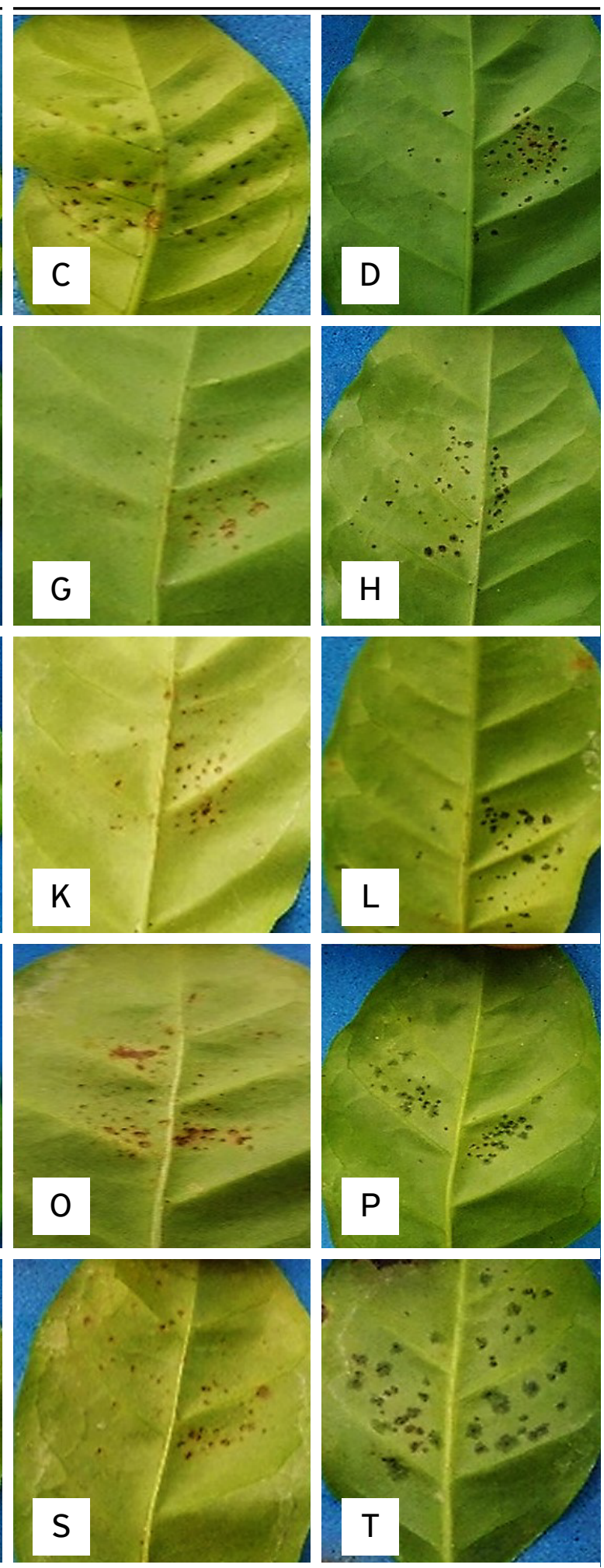

IAC 2160
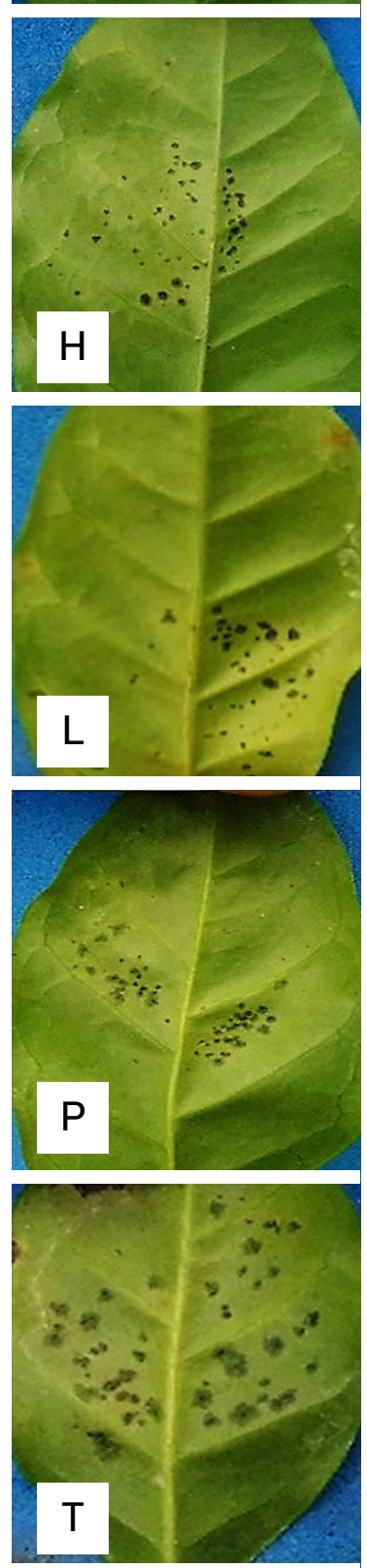

IAC 81

IBSBF: Phytobacteria Culture Collection of Instituto Biológico.

Figure 1. Symptoms at seven days after inoculation on leaves of the first to fifth internodes, inoculated by the abrasion method with Pseudomonas syringae pv. garcae, strain IBSBF 3212 (A, E, I, M and Q) on Coffea arabica IAC 2160 land race, and on leaves of the susceptible Catuaí Vermelho IAC 81 cultivar (B, F, J, N and R). Besides, inoculated with P. syringae pv. tabaci IBSBF 3210 strain, on leaves of IAC 2160 (C, G, K, O and S) resistant access, and on leaves of the susceptible Catuaí Vermelho IAC 81 cultivar (D, H, L, P and T). 
Table 1. Analysis of variance of the data area under the disease progress curve (AUDPC).

\begin{tabular}{lccccc} 
Sources of variation & DL & SS & MS & F \\
\hline Bacterial strains & 4 & $121,157.46$ & $30,289.37$ & $51.275^{* *}$ \\
\hline Pair of leaves & 4 & $50,706.36$ & $12,676.59$ & $21.459^{* *}$ \\
\hline Bacterial strains $\times$ pair of leaves & 16 & $27,852.48$ & $1,740.78$ & $2.946^{* *}$ \\
\hline Residual & 100 & $59,072.4$ & 590.72 & \\
\hline Total & 124 & $258,788.7$ & & \\
\hline
\end{tabular}

DL: degrees of freedom; SS: sum of squares; MS: mean squares; F: F test; ** significantly at $1 \%$ of probability.

Table 2. Area under the disease progress curve (AUDPC) of five pairs of leaves of Catuaí Vermelho IAC 81 coffee cultivar, inoculated with Pseudomonas syringae patovars garcae and tabaci.

\begin{tabular}{|c|c|c|c|c|c|c|c|c|c|c|c|c|}
\hline \multirow{3}{*}{$\begin{array}{l}\text { Strain } \\
\text { IBSBF } 1197^{1}\end{array}$} & \multicolumn{12}{|c|}{ Pair of leaves } \\
\hline & \multicolumn{2}{|c|}{10} & \multicolumn{2}{|c|}{$2^{\circ}$} & \multicolumn{2}{|c|}{$3^{\circ}$} & \multicolumn{2}{|c|}{$4^{\circ}$} & \multicolumn{2}{|c|}{$5^{\circ}$} & \multicolumn{2}{|l|}{ Means } \\
\hline & 281.5 & $\mathrm{aA}$ & 251.2 & $\mathrm{aA}$ & 251.8 & $\mathrm{aA}$ & 242.2 & $\mathrm{aA}$ & 272.8 & $\mathrm{aA}$ & 259.90 & a \\
\hline IBSBF $3212^{1}$ & 236.2 & $\mathrm{bA}$ & 160.9 & $b B$ & 196.6 & $b B$ & 175.9 & $b B$ & 260.2 & $\mathrm{aA}$ & 205.96 & $b$ \\
\hline IBSBF $3210^{2}$ & 284.2 & $\mathrm{aA}$ & 259.3 & $\mathrm{aA}$ & 251.5 & $\mathrm{aA}$ & 244.0 & $\mathrm{aA}$ & 274.3 & $\mathrm{aA}$ & 262.66 & $\mathrm{a}$ \\
\hline IBSBF $3211^{2}$ & 190.3 & $\mathrm{CB}$ & 164.5 & $\mathrm{bBC}$ & 151.6 & cC & 197.8 & $\mathrm{bB}$ & 247.0 & $\mathrm{aA}$ & 190.24 & c \\
\hline IBSBF $2249^{2}$ & 282.1 & $\mathrm{aA}$ & 259.0 & $\mathrm{aAB}$ & 238.6 & $\mathrm{aB}$ & 247.9 & $\mathrm{aAB}$ & 271.6 & $\mathrm{aAB}$ & 259.84 & $\mathrm{a}$ \\
\hline Means & 254.86 & $A$ & 218.98 & B & 218.02 & B & 221.56 & B & 265.18 & A & & \\
\hline
\end{tabular}

Means followed by the same lowercase letter in the columns and, upper case in the lines, do not differ from each other by the Student-NewmanKeuls test at $5 \%$ probability; ${ }^{\text {P }}$ seudomonas syringae pv. garcae; ${ }^{2}$ P. syringae pv. tabaci; IBSBF: Phytobacteria Culture Collection of Instituto Biológico; CV: coefficient of variation.

CFU concentration on inoculated plants. In contrast, coffee plants with intermediary resistance/susceptible levels may not follow this behavior.

According to OLIVEIRA; ROMEIRO (1991), the phenolic compounds, present in higher concentration in fully developed leaves and with greater photosynthetic activity (third pair of leaves), could act as inhibitors of BHB. However, the disease severity caused by high virulent strains may suggest the existence of a more complex pathogenicity mechanism on coffee trees.

Highly virulent strains of $P$. syringae pv. garcae IBSBF 1197 and P. syringae pv. tabaci IBSBF 3210 were able to infect leaves in all physiological stages of coffee trees, differing from other strains within the species due to the better adaptability to their patossystems, probably by the increasing of quorum sensing (QUIÑONES et al., 2005) control, resulting in a more efficient virulence genes expression.

From this exploratory study, we can suggest that the first three pairs of leaves should be inoculated for virulence evaluation of bacterial strains. The early resistant plants selection can be accurately performed by inoculations of highly virulent strains on younger leaves and evaluations carried out in a short period.

Our results showed that, under optimal conditions, the two pathovars have the same pathogenic ability on young and old leaves, making it difficult to adopt disease management measures in the field, and the presumptive diagnosis of diseases. It should be emphasized that, although BLS may be restricted to some producing regions, it is as aggressive as BHB. To avoid economic damage associated with these complex diseases, caused by $P$. syringae on coffee crop, further studies are required.

For this reason, in addition to the high similarity of $\mathrm{BHB}$ and BLS symptoms, it is essential to perform a prospection of P. syringae pv. tabaci on different Brazilian coffee producing regions, in order to determine the pathogen distribution and variability precisely.

\section{ACKNOWLEDGEMENTS}

The authors thanks to Dr. Julio Rodrigues Neto for his critical comments, to the Brazilian National Council for Scientific and Technological Development (CNPq), for research fellowship (OGF CNPq DT 313.796/2009-02, ALMRT CNPq PIBIC 115.621/2016-4) and financial support (grant CNPq 479.589/2013-5) and CAPES Foundation (LMRR and VTA) for research fellowship. 


\section{REFERENCES}

AMARAL, J.F.; TEIXEIRA, C.G.; PINHEIRO, E.D. O bactério causador da mancha aureolada do cafeeiro. Arquivos do Instituto Biológico, v.23, p.151-155, 1956.

DESTÉFANO, S.A.L.; RODRIGUES, L.M.R.; BERIAM, L.O.S.; PATRÍCIO, F.R.A.; THOMAZIELLO, R.A.; RODRIGUES-NETO, J. Bacterial leaf spot caused by Pseudomonas syringae pv. tabaci in Brazil. New Disease Reports, v.22, p.5, 2010.

ITO, D.S.; SERA, T.; SERA, G.H.; DEL GROSSI, L.; KANAYAMA, F.S Resistance to bacterial blight in arabica coffee cultivars. Crop Breeding and Applied Biotechnology, v.8, n.2, p.99-103, 2008. doi: 10.12702/1984-7033.v08n02aO1

LELLIOT, R.A.; BILLING, E.; HAYWARD, A.C. A determinative scheme for the fluorescent plant pathogenic Pseudomonads. Journal of Applied Bacteriology, v.29, n.3, p.470-489, 1966. https://doi. org/10.1111/j.1365-2672.1966.tb03499.x

MOHAN, S.K.; CARDOSO, R.M.L.; PAIVA, M.A. Resistência em germoplasma de Coffea ao crestamento bacteriano incitado por Pseudomonas garcae Amaral et al. Pesquisa Agropecuária Brasileira, v.13, n.1, p.53-64, 1978.

OLIVEIRA, J.R.; ROMEIRO, R.S. Reação de folhas novas e velhas de cafeeiros a infecção por Pseudomonas cichorii e $P$. syringae pv. garcae. Fitopatologia Brasileira, v. 15, p.355-356, 1990.

.; ______. Compostos fenólicos, idade das folhas e resistência do cafeeiro a Pseudomonas cichorii e Pseudomonas syringae pv. garcae. Revista Ceres, v.38, n.220, p.445-452, 1991

; MUCHOVEJ, J.J. Population tendencies of Pseudomonas cichorii and $P$. syringae pv. garcae in young and mature coffee leaves. Journal of Phytopathology, v.131, n.2, p.210214, 1991. https://doi.org/10.1111/j.1439-0434.1991. tb01190.x

QUIÑONES, B.; DULLA, G.; LINDOW, S.E. Quorum sensing regulates exopolysaccharide production, motility, and virulence in Pseudomonas syringae. Molecular Plant-Microbe Interactions, v.18, n.7, p.682-693, 2005. https://doi.org/10.1094/ MPMI-18-0682

RODRIGUES, L.M.R.; ALMEIDA, I.M.G.; PATRÍCIO, F.R.A.; BERIAM, L.O.S.; MACIEL, K.W.; BRAGHINI, M.T.; GUERREIRO FILHO, O. Aggressiveness of strains and inoculation methods for resistance assessment to bacterial halo blight on coffee seedlings. Journal of Phytopathology, v. 165, n.2, p.105-1 14, 2017a. https://doi. org/10.1111/jph.12543

; SERA, G.H.; GUERREIRO FILHO, O.; BERIAM, L.O.S.; ALMEIDA, I.M.G. First report of mixed infection by Pseudomonas syringae pathovars garcae and tabaci on coffee plantations. Bragantia, v.76, n.4, p.543-549, 2017b. http://dx.doi. org/10.1590/1678-4499.2016.399

STATISTICAL ANALYSIS SYSTEM INSTITUTE. User's guide: Statistics. SAS Inst., Cary, NC, 2009.

SERA, T. Coffee Genetic Breeding at IAPAR. Crop Breeding and Applied Biotechnology, v.1, n.2,b p.179-199, 2001.

STEEL, R.G.D.; TORRIE, J.H. Principles and procedures of statistics: a biometrical approach. 2nd ed. Boston: McGraw-Hill Companies, 1980. 633p.

VAN DER PLANK, J.E. Plant diseases: epidemics and control. New York: Academic Press, 1963. 349p.

WOLF, E.A.; FOSTER, A.C. Tobacco wildfire. Journal of Agricultural Research, v.12, p.449-458, 1918.

YOUNG, J.M.; DYE, D.W.; BRADBURY, J.F.; PANAGOPOULOS, C.G.; ROBBS, C.F. A proposed nomenclature and classification for plant pathogenic bacteria. New Zealand Journal of Agricultural Research, v.21, n.1, p.153-177, 1978. https://doi.org/10.10 80/00288233.1978.10427397

ZOCCOLI, D.M.; TAKATSU, A.; UESUGI, C.H. Ocorrência de manchaaureolada em cafeeiros na Região do Triângulo Mineiro e Alto Paranaíba. Bragantia, v.70, n.4, p.843-849, 2011 . http://dx.doi. org/10.1590/S0006-87052011000400017 